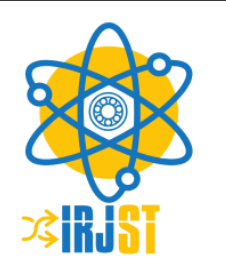

Available online at https://www.irjst.com/

International Research Journal of Science and Technology

ISSN:2707-3955

DOI: https://doi.org/10.46378/irjst.2019.010103

\title{
A Review of Eco-Friendly Preservative and Bio-Tannin Materials Using Powdered Barks of Local Plants for the Processing of Goatskin
}

\author{
Franco John Unango ${ }^{1,2^{*}}$, Ramesh Duraisamy ${ }^{2}$ and Karthikeyan M Ramasamy ${ }^{2}$ \\ ${ }^{1}$ Department of Chemistry, College of Education,University of Bahr el Ghazal, Wau, South Sudan. \\ ${ }^{2}$ Department of Chemistry,Arba MinchUniversity, Arba Minch, Ethiopia.
}

Published : 2019

\begin{abstract}
Skin is a raw material which is considered as the heart of leather making process. Skin falls vulnerable upon the flayed of the animals and is seriously invaded by bacteria if it is not well protected. Curing and preservation of raw stock resist putrefaction and reserve leather quality. Worldwide, most commonly used skin preservation is by using table salt which is accused of polluting the environment by increasing soil salinity, affecting water body, releasing more than $40 \%$ dissolved solids and $55 \%$ chlorides etc. Further, on the side of leather tanning, $80-90 \%$ of all leathers is manufactured by tanning with basic chromium (III) salt, because of its excellent features and is also solemnly accused that; its safety record is cautionary, uncontrolled emission of chromium (VI) and it is a limited natural resources. Pollution control authorities of many countries are imposed severe restrictions on both salt preservation and chrome tanning forcing the tanners and researchers to look for possible alternative ways that are naturally abundant, easily obtainable, low priced, eco-friendly and offer competitive with existing tanned leather performances. The critical reviewed was targeting the recent alternatives trends to skin/hides salt preservation as well as vegetable tanning as a possible way to replace the use of basic chromium salt for the sustainability of leather industry and to further suggest another preservative and vegetable plant to be used in future studies.
\end{abstract}

\section{Key Words}

Bio-tanning

Chrome-free

Eco-friendly

Hageniaabyssinica

Leather

Preservation

Goatskin

Natural Plant

Copyright@2019:Franco John Unango, Ramesh Duraisamy and Karthikeyan M Ramasamy..This is an open access distribution, and reproduction in any medium, provided Access article distributed under the Creative Commons Attribution License the original work is properly cited License, which permits unrestricted use.

Citation:Franco John Unango, Ramesh Duraisamy and Karthikeyan M Ramasamy. "A review of eco-friendly preservative and bio-tannin materials using powdered barks of local plants for the processing of goatskin ", International Research Journal of Science and Technology, 1(1), 13-20, 2019

\section{Introduction}

\subsection{The Skin}

Skin/hide is a complex structure, providing protection against the environment and affording temperature control. Skins are raw materials which are considered to be the heart of the leather making process. Skins in their raw state consist of three layers such as

\footnotetext{
${ }^{*}$ Corresponding author : Franco John Unango

Department of Chemistry, College of Education,

University of Bahr el Ghazal, Wau, South Sudan

Email: majigoifranco@gmail.com
}

epidermis/outer layer (composed of soft keratin), the corium (rich in protein collagen gives leather the strength and resiliency), and adipose tissue/flesh which is stronger and has a controlling effect on the area of the skin or leather [1]. Skin is made up of a protein polymer called collagen but the main ingredients of the raw hide/skin materials are about $60-70 \%$ of moisture $\&$ nearly $25-30 \%$ proteins, $2 \%$ fats, remains carbohydrates and mineral constituents. In this form it is disposed to bacterial activity and the degradation starts within 5-6 hrs. The bacteria on the rawhides/skins may penetrate the corium from the flesh surface in 8-12 hrs. 
The bacteriamyales has serious grain peeling and voids in the hide/skin from 5-24 hrs. Putrefaction of hides/skins is decay of protein and other materials. The mechanism of putrefaction is the production of enzymes by bacteria; hence it is essential to preserve the protein matrix of skin before converting it into leather for better qualities of end products [2].

\subsubsection{Curing and Preservation}

When the animal is slaughtered the nature's defense mechanism ceases to function and the invaded bacteria then become active which start to decomposing the skin. The commonest bacteria on the clean raw skin are from gram positive cocci a single genus Staphylococcus. But storage skin harbor mainly gram negative Enterobacteriaceae and Alcaligens. Curing and preservation of raw stock has the objective of rendering the freshly flayed pelt resistant to putrefaction to allow transport and storage. This could be either by destroying active bacteria, preventing bacterial activity or by preventing bacterial contamination [3]. The putrefaction reactions include the hydrolysis of triglyceride fat to free fatty acids and glycerol by lipases and the breakdown of carbohydrates into sugars by carbohydrase enzymes. The effects of in-adequate preservation include; loss of hide substance, increase in free fatty acid, and damage to grain if the bacteria reached the grain-corium junction and loss of structural fiber [4].

\subsubsection{Negative Aspects of Salt Preservation}

The most commonly used preservation method is the one by using common salt $(40-50 \% \mathrm{NaCl})$ for preservation of skin/hide. Under this process moisture content of hide/skin is reduced from $65 \%$ to $30 \%$ and it's making the condition non-conducive for the bacterial growth. The method is cost effective and easy to practice; nearly 8 million tons of raw hides and skins are processed worldwide annually using common salts [5]. In contrast, it is estimated that about 3 million tons (annually) of untreated salt are discharged during leather processing and this leads to significant addition of salinity to the soil [6]. The transportation of salt into ground water affects the water bodies in the region posing major environmental challenges. Salt used in curing contributes to more than $40 \%$ of TDS and about $55 \%$ of chlorides in the composite tannery effluents [7]. Nearly $70 \%$ of the pollution loads of BOD, COD, and TDS that are generated during soaking, liming, degreasing, pickling and tanning processes. There is a gigantic pressure from the various pollution control bodies to regulate and minimize the amount of pollution generated from the beam-house operations. The need for use of alternatives to chemical methods to fight pollution problem have become necessary to protect the industry and to comply with the environmental standards. It has been revealed that pretanning and tanning processes contribute $80-90 \%$ of the total pollution load in respect to BOD, COD, TS, TSS, TDS, $\mathrm{Cr}^{6+}, \mathrm{S}_{2}{ }^{-}, \mathrm{Cl}^{-}$, etc [8].

\subsubsection{Chrome Tanning}

Leather tanning is the process of introducing a stabilizing or tanning agent into the hide/skin in order to convert it into leather. Tannic acid and other chemicals of the plants are absorbed by hides and skins making them resistant to putrefaction, wetting, and keep them flexible and long-lasting. Today $90 \%$ of all leathers are manufactured with chrome tanning agents. Chromium salts are used widely in leather-making because of its excellent features; no any other single tanning agent can displace it absolutely. However, three negative attributes pose serious challenges to continue reliance on tanning with chromium; that's it is limited natural resources, its safety record is cautionary and uncontrolled emission can have serious environmental impact [9]. Now days, seeking the new tanning agent to wholly replace basic chrome sulphate with environmental eco-friendly and excellent features have become an obligatory and challenge to all researchers and tanners worldwide.

\subsubsection{Vegetable tanning (Bio-tanning)}

Vegetable tannins are polyphenolic compounds that are widely distributed in plants which have the property to precipitate proteins. Since ancient times, this property has been empirically explored to transform animal skins into leather. The termed vegetable tanning is one of the oldest known leather making processes and it is the treatment of hides/skins with pulverized barks, leaves, wood, fruits, pods or galls, or their extracts, obtained from different vegetable sources. Vegetable tannins react with collagen primarily via hydrogen bonding [10]. Vegetable tanning is considered as green tanning agent and the most promising one because of its biodegradation and friendly to environment. Vegetable tannage is having many advantages on the tanned leather such as excellent fullness, durability, wear resistance, solidness, air permeability, etc. however, the future gifted is on vegetable tanning to replace chromium tanning.

\subsection{Significance of the Review}

Skins are abundantly produced everywhere all over the world in each and every country. Skins, the natural outer stratums which cover animals' skeleton and are considered the byproduct of meat industry, it is used as 
the basic raw material for the leather industry. To avoid the putrefaction of hides/skins, there is a need to protect them in order to attain better qualities of leather products. The review assessed for the newly developed preservation and bio-tanning methods with regard to environmental pollution, economic aspect and leather qualities. This review may enable the researchers to develop newer preservation system as an alternative to table salt method, add the new knowledge and give broader outlook of utilizing plants' ash in the curing and preservation of raw skins and help to promote green technology which is beneficial to the country in term of cleaner production development technologies.

\section{Review of Literature}

\subsection{Nature of Raw Hides and Skins}

Hides and skins are raw materials which are considered to be the heart of the leather making process. As the largest organ of the body of mammals, the skin/hide is a complex structure, providing protection against the environment and affording temperature control. Hides and skins composed of proteins (see Fig.1), fats, carbohydrates, mineral matters and water.

The protein collagen is the properties and potential for chemical modification that offer the tanner the opportunity to make a desirable product from starting material [12]. Hide and skins in their raw state consist of three layers, the epidermis (outer layer), the corium, and adipose tissue (flesh) (shown in Fig.2). The corium layer is rich in protein (collagen form) and it gives the strength and resiliency to leather. Individual collagen molecules combine together in the corium to form very small fibrils that are in turn bound together to form collagen fibers, which are visible under the microscope. The strength of the skin and leather is due to cross weaving of these fibers [13]. The environmental pollution in leather manufacturing could be reduced by direct processing of hides after flaying. The hide/skin could not be left unprocessed for more than four hours, after which hide would putrefy and could be lost completely, if chilling system may not be adopted for hides/skins [14].

\subsection{Cross linking of Collagen}

The collagen molecule like all proteins, it is formed by the linking together of naturally occurring smaller units of amino acids. All amino acids contain a carboxyl and an amino group, with a side chain denoted as ' $R$ '. Collagen cross-linking contributes to the tensile strength of tissues such as tendon and it is important in stabilizing the collagen fibrils. It is classified into: (1) Natural cross-linking that crosslinks between the molecules making up the fibres determine the strength of the collagen fibres. These

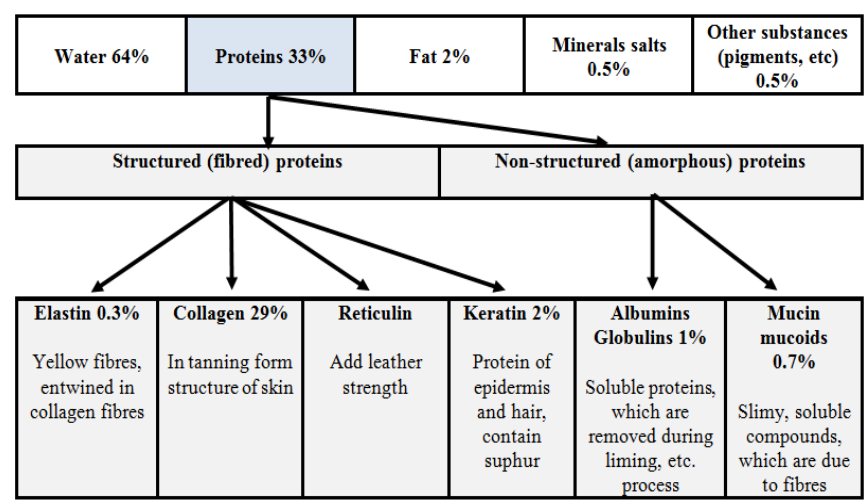

Figure 1. Chemical composition of skin/hide [Ref. 11]

cross- links are covalent bonds formed between the individual molecules within the fiber at highly specific points, controlled by the precise alignment of the fibre [15]. (2) Artificial cross-linking: Reconstituted forms of collagen, such as films, fibres or sponges, can lack strength and may disintegrate on handling or collapse under the pressure from surrounding tissue in vivo, due to dissociation of cross-links in the isolation processes. As a consequence, mechanical resilience and collagenase resistance of the collagen is often necessarily conferred by introducing artificial crosslinking into the molecular structure of collagen as used in leather tanning. E.g. trivalent chromium salts, aluminum and polyvalent cations, etc. are used as cross-linking agents to form covalent bonds with collagens (see Fig.3) [16].

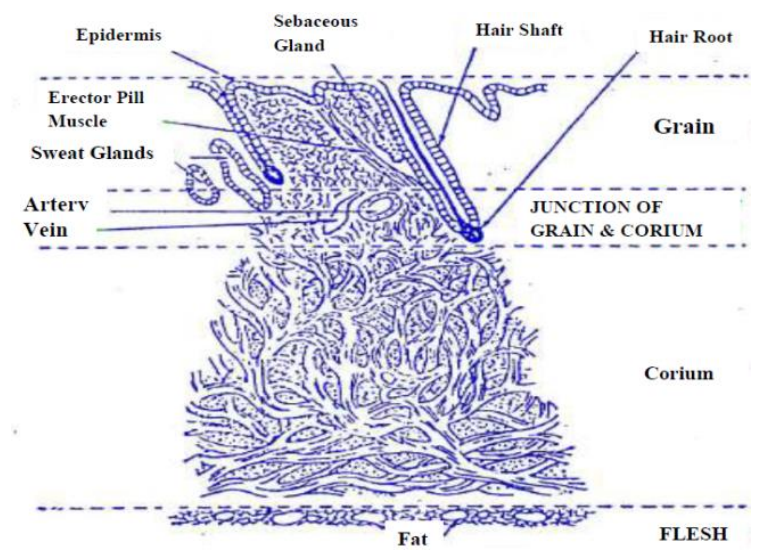

Figure 2. Cross-section of hides and skins [Source: ref. 14] 


\section{COLLAGEN-CHROMIUM CROSSLINKING}

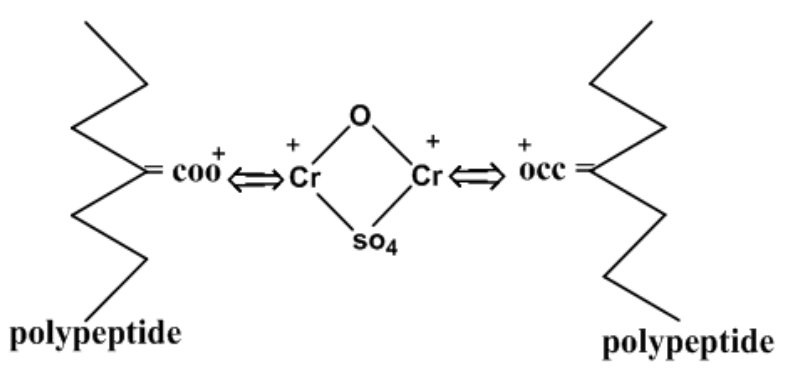

Figure3. Collagen-chromium cross-linking [Ref. 16]

\subsection{Preservation Using Common Salts}

Research have being carried out worldwide in search for salt-less or less salt alternative curing systems regarding the environmental pollution caused by the used of salt in hide/skin preservation. Yet none of them is compatible and accepted to replace salt without secondary challenges. The common bacteria on the clean raw skin belong to gram positive genus Staphylococcus. But storage skin harbor mainly gram negative Enterobacteriaceae and Alcaligens [3]. The transport of salt through ground water affects the water bodies in the region posing major environmental challenges. Salt used in curing (shown in Fig.4) contributes to more than 40\%TDS and 55\% chlorides in the composite tannery effluent [7]. The subsequent processing of salt preserved skins in tanneries results in the generation of large quantities of total dissolved solids (TDS) and $\mathrm{Cl}^{-}$. The pollutants that are very difficult to treat; consequently, tanners have been forced to search for better alternatives. Salt free and less salt preserving systems based on boric acid have been investigated and evaluated at ambient temperature of $30-35^{\circ} \mathrm{C}$ as alternative preservation systems but yet it is not in use [18]. In first operation, the soaking process alone releases nearly $40-50 \%$ of the TDS of the entire leather processing [6]. Researchers and scientists have investigated a number of preservation systems such as potassium chloride [19], soda ash [20] and preservatives such as benzalkonium chloride [21], antibiotics such as aureomycin, terramycin [22], radiation curing by using gamma rays (photon emission from radioactive materials) and electron beams for preserving the skin/hide have been explored [23] and formaldehyde was also used as the curing agent [24]. In dry regions, TDS is turning into the main opponent of tanning industry. The effect of salinity from tanning sector on the ground water and infertility of the soil has been reviewed [25].The herbal Rumexabyssinicus (mekmeko) roots, which were shade dried and grounded into powder was used for preserving goat skins and its potential effectiveness was analyzed. The efficacy of this new preservation method was assessed at different curing period for a month, and yet is not in used [26].The bacteria on the raw hides/skins may penetrate the most important part of the skins (corium) from the flesh surface in 8-12 hrs. The bacteria may also form serious grain peeling and voids in the hide in 15-24 hrs [2]. Much of the pollution load generated such as COD, TDS, chlorides, sulfates and heavy metal pollution are produced during pre-tanning operation. The chemicals discharged into aquatic systems end up in highly polluted sediments and salinity of rivers. European chemical agency (ECHA) has prioritized some of the hazardous chemicals used under substances of very high concern (SVHC) and substances for authorization; the situation has highlighted the need for greener technologies [27].

\subsection{Pre-tanning (Beam house) Operations}

The term 'beam house' 'refers to the process in the tannery between removal of the skins/hides from storage and their preparation for tanning (soaking to pickling). The term is dated back to the time when the hair was removed from the skins by means of a hand beam; which was carried out on sloping curved table or large log; known as beam and by using a two handled curved knife for hair removal. These operations include soaking, trimming, fleshing, unhairing, liming, de-liming, bating and pickling (Shown in Fig.6). Indeed in the opinion of most practical tanners, "leather is made in the beam house" or in modern saying "leather is married in the beam house" [28].

Conventional leather manufacture involves various physicochemical treatment processes leading to the generation of wastewater with high pollution load. Several alternative leather chemicals and in-process control measures have been developed to overcome the environmental issues [17].The pickling process contributes to TDS in the form of chlorides considerably and this is not agreeable to treatment via currently used end-of-pipe treatment methods [29]. About 130 chemicals are used in leather manufacturing ranging from common salt to the very expensive chrome sulphate. All three categories of wastes i.e. gaseous (air emissions), liquid (wastewater) and solid (solid wastes) are generated from the tanneries worldwide [11].The principles behind each step reveals that the bulk of the pollution rests in pretanning and tanning processes, it causes increase in COD, BOD, TDS, TSS, chlorides and sulphates in tannery effluents [9]. 


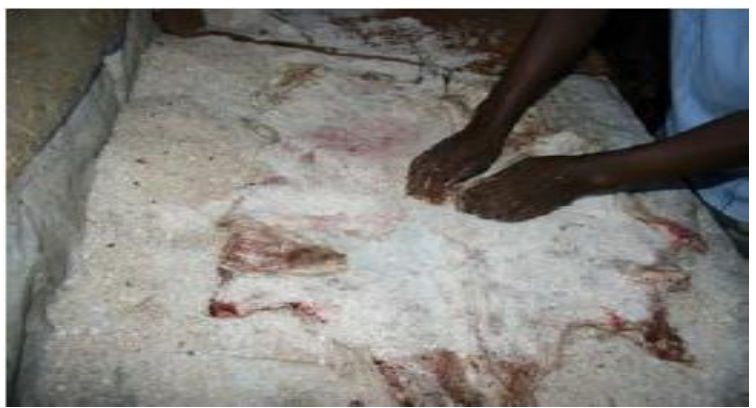

Figure 4. Demonstration of salting during ESGPIP training in Semera, Afar region - Ethiopia [Ref. 17]

\subsection{Chrome Tanning}

The tanning properties of chromium (III) salts were discovered at the end of the nineteenth century. About $80-90 \%$ of all the leather produced today is tanned using chromium (III) salts. Tanning with basic chromium sulphate is having many advantages such as high hydrothermal stability, good strength characteristics, good affinity and compatibility with dyes, retanning materials, fat liquors and finishing materials. The possible formation of chromate in leather during its manufacture depends on synergetic effects of several components. The raising of the $\mathrm{pH}$ during the neutralization of wet blue facilitates the oxidation of chromium (III) to chromium (VI)). The drying of leather and its intermediate products may also create favorable conditions for the formation of chromium (VI) [30]. Chromium salts used in tanning enters the pores of the skin by a diffusion process to react with the collagen carboxyl groups and form interand intra-molecular cross linking (shown in Fig.5) which results in physical, chemical and biological stability of the leather. In contrast, chrome tanning uptake only $60-65 \%$ of the chromium offered to the leather and the discharged chromium effluent poses chromium (VI) which is carcinogenic and can cause damage to skin, mucous membrane, respiratory tract, kidney etc [31].

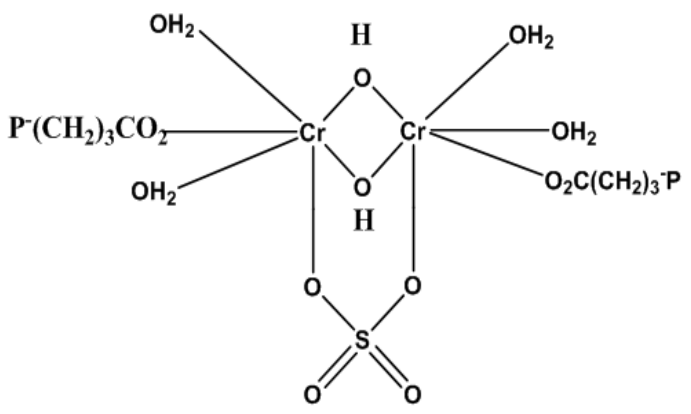

Figure 5. Interaction of chromium complex with collagen[Ref. 32]

\subsection{Bio-tanning}

The bio-tanning is the tanning of hide or skin by utilizing vegetables, animals' brain and microorganism to produce leather. Bio-tanning is also considered as the "green tanning agent" because of its biodegradation and environmental friendly as well as can be easily applied for a variety of sorts. Bio-tanned leather has excellent fullness, moldering properties, wear resistance, air permeability and solidness; therefore, it is of greater importance to reduce chrome pollution in leather manufacturing. The leathers tanned with vegetable were used to produce shoes, stiff, belts, wallets, holsters, helmets, saddles, harnesses, pouches, bellows, etc [33].

\subsubsection{Bio-tanning Materials}

Tannins are widely distributed in plants in the form of powder, flakes, or spongy mass, which are pale-yellow or light brown in color. The substance can be found in the bark, roots, leaves, woods, fruits, pods, and cups of most plants [34].Tannins combine to the collagen proteins in the hide/skin and causing them to turn into less water-soluble, and more resistant to bacterial breakdown. The factors that affect leaching are mainly time, solvent to solid ratio, temperature, agitator speed and time of extraction. The gallotanninsandellagitannins make leathers become pink, red or dark brown shades that are more solid. They also create greenish-black spots on contact with iron [35]. Plant phenolics and polyphenols are secondary natural metabolites arising biogenetically from either the phenylpropanoid pathway, which directly provides phenylpropanoids, or the polyketide pathway, which can produce simple phenols, or both. Plant phenolics are considered to have a key role as defense compounds when environmental stresses, such as high light, low temperatures, pathogen infection, herbivores, and nutrient deficiency, can lead to an increased production of free radicals and other oxidative species in plants [36].

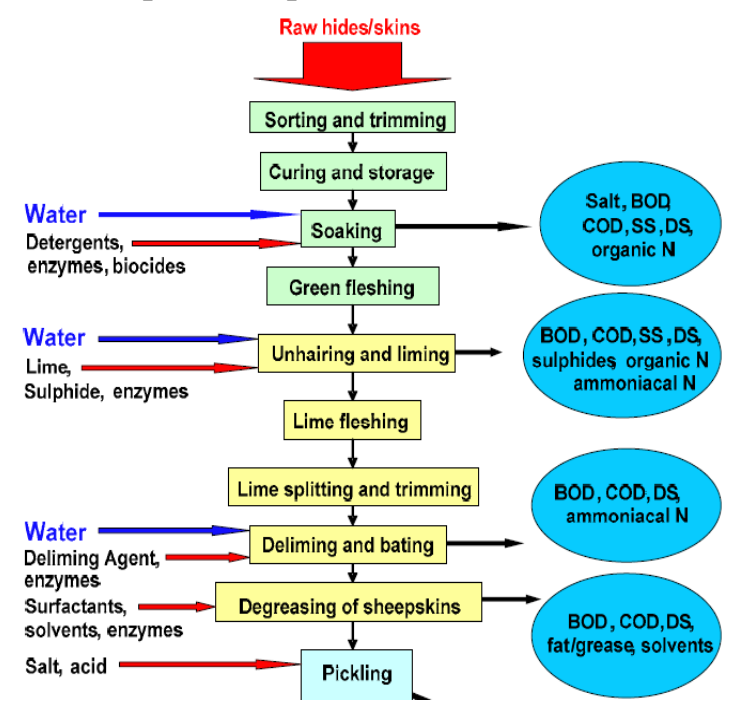

Figure 6a. Main input and aqueous effluents in Leather processing [Ref. 34] 


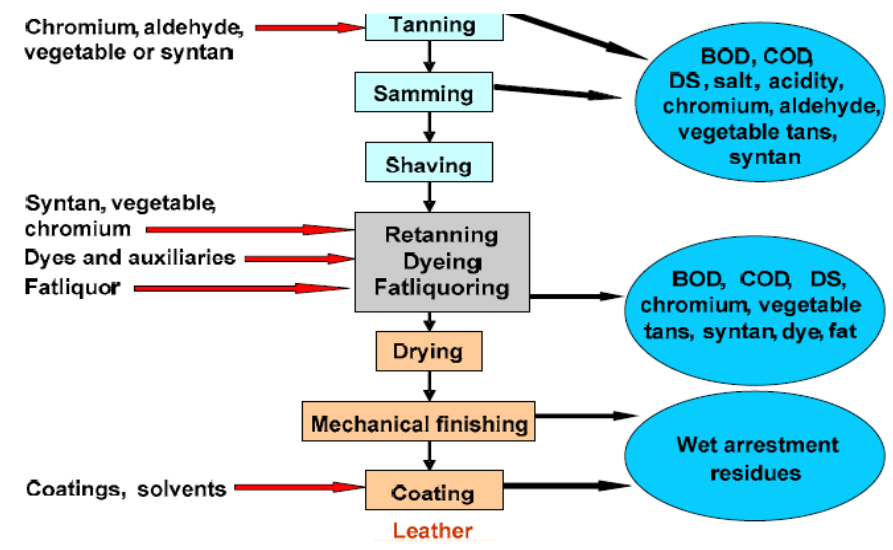

Figure 6b. Main input and aqueous effluents in Leather processing

\subsubsection{Vegetable Tanning}

Vegetable tanning is the oldest known leather making processes and was done by treating the hides and skins with leaves and barks containing tannin. Many ancient peoples tanned their leather by placing layers of bark, leaves, seeds and fruit over the hides and then adding water. Vegetable tanning is the most eco-friendly method of tanning compared to other methods and it discharge minimum pollutants to the environment. Vegetable tanning of light leathers required 18-20\% tannins and that of heavy leathers require $25-30 \%$ tannins[37].Vegetable tannins or natural polyphenols (see Fig.7) are water soluble, relative molecular masses in the range 500-3000 and besides giving the usual phenolic reactions; they are able to precipitate some alkaloids, gelatin, and other solution from protein [38]. Vegetable tanning is divided intothree parts:

(1) Hydrolysable (pyrogallols) are esters of glucose andgallic acid and its derivatives which are easily hydrolizable to the respective sugar or polyhydric alcohol and polyhydric phenol with carboxyl group. It is classified into gallotannins, derivatives of gallic acid, and ellagitannins, derivatives of ellagic acid.

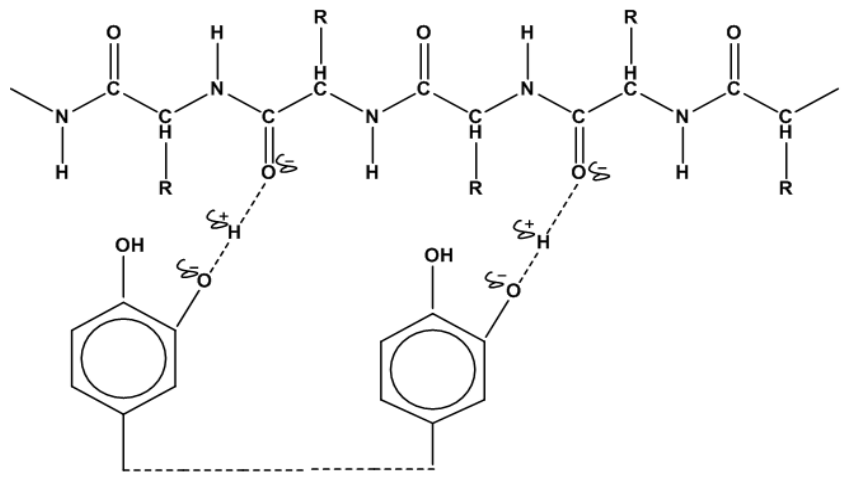

Figure 7. Model of the interaction between plant polyphenol and collagen [Source: ref. 40]
(2) Catechol tans (condensed tans) are not decomposed by acids. They gradually polymerize becoming phlobaphenes, insoluble derivatives.The flavonoid compounds are typically less astringent and react with collagen via hydrogen bonds. (3) Complex tannins are mixtures of tannin types, in which a hydrolysable gallotannin or ellagitannin moiety is bound glycosidically to a condensed tannin moiety [15]. A study done in Ethiopia on local knowledge of plants and their use in Bale mountain revealed that the extracts from the bark of Hageniaabyssinica was used for softening leathers, paints and as medicinal plants [39].Hageniaabyssinica has not been widely used in leather production as compared to Acacia nilotica but it has the minimum tannin contents of $11.73 \%, \mathrm{pH}$ 4.96 and tanning strength of 2.1. The leathers tanned with Hageniaabyssinica yielded a tearing strength of $31.25 \mathrm{~N}$, tensile strength of $27.91 \mathrm{~N} / \mathrm{mm}^{2}$ and shrinkage temperature of $80^{\circ} \mathrm{C}$ [37].

\subsubsection{Vegetable Tanning Materials}

Vegetable tannins are polyphenols with molecular weight ranging 500-3000, present in vegetable tanning materials and in its extract. The materials are obtained in the form of wood, bark, fruit and leaves from various plants [41].The type, the maturity and sources of vegetable tanning materials have an impact on the quality of leather regardless of tanning and posttanning. Vegetable tanning uses vegetable materials to process animal hides/skins into water proof, nonputrefiable, soft, supple and heat. Vegetable tanned leather is used in making upper leather such as furniture leather; shoe upper leather, etc. [34]. The plant parts used for tanning in order of their importance were barks, roots and tubers with animal fat and brains the lowers [36].

\subsubsection{Extraction of Tannins from Vegetations}

There is no fixed procedure for the extraction of tannin materials from the plant parts worldwide, but it varied based on whether the tannins indented to extract should be solid/powder or liquid. Traditionally the tannins have been extracted with water as solvent. However, commercial vegetable tannin extracts/tan liquors are mixtures of polyphenolic compounds with a definite tannin-non tannin ratio, astringency and other plant products. The assembly of vegetable tannin extracts depend on the suitable solvent usually water and followed by concentration and spray drying to get powder or solidification to get solid extract [42].

\section{Conclusion}

The terrible restrictions inflicted by the pollution control authorities on both salt preservation and chrome tanning in leather manufacturing have forced 
the tanners and researchers to seek possible alternatives that are naturally abundant, easily obtainable, low operational cost, eco-friendly and offer competitive tanned leather performances. Preservative derived from the ash of plants had never been tried as green preservatives for curing of skin/hide. Plant ash is likely usable in curing and preserving hide/kin and to give broader outlook of utilizing plants' ash rather than considered to be domestic waste. Moreover, among several researches done on chrome-free tanning, none of them have used Hageniaabyssinica plant tannins.Hageniaabyssinica has not been widely used in leather production as compared to Acacia nilotica, mimosa, etc but the extracts from the bark of Hageniaabyssinica has been traditionally used for softening leathers and as medicinal plants by the communities of Ethiopia. As a result, this review has recommended the use of eco-friendly preservative from plants ash and bio-tanning by using the barks' powdered of Hageniaabyssinica as new cleaner technologies in leather processing in order to wholly replace the conventional curing and preservation with sodium chloride and tanning by using basic chromium sulphate.

\section{Scope for the Further Work}

Different methods of curing and preservation have been tried in different situations in different countries; but the most dominated method, is the one with common salts $(\mathrm{NaCl}$ that contributes more of TDS and chlorides on tannery effluents, hence polluting the environment, causing infertility of soils, land degradation, pollution of the underground water, etc. Again today most of the leathers are being manufactured with chrome tanning agents because of its excellent features and no any other single tanning agent can displace it wholly. But, it has cause of environmental issues. Therefore, tanners and researchers found it difficult to comply with emerging regulations with respect to chrome content of effluents as well as the disposal of chrome containing solid wastes. Several researchers have done on both; preservation with salt and chrome tanning but none of them have used plant ash preservatives and Hageniaabyssinica plant tannins.Hageniaabyssinica has not been widely used in leather production as compared to Acacia nilotica, mimosa, etc but the extracts from the bark of Hageniaabyssinica has been traditionally used for softening leathers, paints and as medicinal plants by the communities of Ethiopia. As a result, this review has recommended that there is a need to introduce a new cleaner technologies of preservation of skin/hide by using eco-friendly preservative from the ashes of green plants and biotanning could be employing by using the barks of
Hageniaabyssinica with intentions to eliminate or reduce the amount of polluting discharges along with the processed medium of wastewater.

\section{References}

[1]. Thorstensen, T. C. (1993) "Practical Leather Technology (Fourth ed.) Malabar: Krieger Publishing Company".

[2]. Emel, A., Meral, B. (2011) "Examination of Gram Positive Bacteria on Salt Pack cured Hides" J. Amer. Leather Chem. Ass, 106 (373).

[3]. SivabalanV. and Jayanthi A. (2009) "A Study to Reduce Salt Usage in Preservation of Skins and Hides with Alternate use of Plant Extract", 4 (6)

[4]. Kanagaraj.J. (2014) "Effective Preservation of Raw Goat Skins for the Reduction of Total Dissolved Solids", Adyar, Chennai (600 021), India.

[5]. Buljan J. (2005) "Salinity within Tannery Effluents", World Leather, 18 (1-4) pp.18-20.

[6]. Daniels R. (1997) "Overview: Avoiding Salts", World Leather, 10 (2-7) pp.41-45.

[7]. Kanagaraj and Chandra B. (2002) "Alternative to Salt Curing Techniques - A Review". JSIR 61,pp.339-348.

[8]. Burrows, G.H. (2001) "Clean Technology in the Processing of Leather", Proceedings of the XXVI IULTCS Congress, Cape Town.

[9]. PalanisamyThanikaivelan, et al.(2005) "Recent Trends in Leather Making: Processes, Problems, and Pathways", Critical Reviews in environmental Science and Technology, 35 (1), pp. 37-79.

[10]. Covington A.D. (2009) "Tanning Chemistry: The Science of Leather, Royal Society of Chemistry, Cambridge"

[11]. Sumita D., Ashish Y., Premendra D. D., Mukul D.(2015) "Toxic Hazards of Leather Industry and Technologies to Combat Threat a Review", JCP 7. pp 39-49.

[12]. United States Agency for International Development (USAID) (2013) "Value Chain Analysis for Ethiopia: Meat and Live Animals, Hides, Skins and Leather and Dairy. Expanding Livestock Markets forthe Small-Holder Producers", AGP-Livestock Market Development Project, AID-663-C-12-USAID/Ethiopia.

[13]. Daniels R. (2005b) "The Effects of Salinity on the Treatment of Tannery Effluents and Sludge", World Leather, 18 (11) pp. 30-32.

[14]. Varaidzo D., Kumbi M., Tauyanashe C. (2012) "A Cleaner Production Exercise of a LeatherManufacturing Company", A Zimbabwean Experience, Vol.1, pp. 2277-8616. 
[15]. MelkamuKassahunMequannintand

B.Chandrasekaran (2014) "Quebracho-Zinc Sulphate Combination as Chrome free Tanning Agent". Thesis a case study.

[16]. Covington, A. D., Lampard, G. S., Hancock, R.A. and loannidis, I. A. (1998) "Studies on the Origin of Hydrothermal Stability: A New Theory of Tanning”, JALCA.93, pp.107-120

[17]. Dandira, V.S., Madanhire (2013) "Design of a Cleaner Production Framework to Enhance Productivity", Case Study of Leather Company, International Journal of Science and Research (IJSR), India.

[18]. Kanagaraj.J. etal. (2015)“'Alternatives to Sodium Chloride in Prevention of Skin Protein Degradation", Adyar, Chennai (600020), India.

[19]. Bailey David G. andGosselin Joseph A. (1996) "The Preservation of Animal Hides and Skins with Potassium Chloride" Journal of American Leather ChemAssoc 91, pp.317-33.

[20]. Rao BR, Henrickson RL. (1983) "Preservation of Hides with Soda Ash"J Am Leather Chem.Assoc.78.pp.48-53.

[21]. Cordon TC, Jones HW, Naghski J, Jiffee JW. (1964) "Benzalkonium Chloride as a Preservative for Hide and Skin", J Soc Leather Trade Chem.,59, pp.317-326.

[22]. Berwick PG, Gerbi SA, Russel AE. (1996) "Use of Antibiotics for Short Term Preservation", J Soc Leather Trade Chem.74, pp.142-50.

[23]. Bailey DG. (1997) "Evergreen Hide Market Ready”. Leather Manufacturing, 115, pp.22-26.

[24]. Sharphouse JH, Kinweri G. (1978) Formaldehyded Preservation of Raw Hides and Skins", J Soc Leather TechnolChem, 62, pp.11923.

[25]. Daniels R. (2005a) "The Real Cost of A Kilo of Salt", World Leather, 18 (1-4) pp. 20-27.

[26]. Shegaw Ahmed Mohammed, et al (2016) "Rumexabyssinicus (mekmeko) Ethiopian Plant Materia for Preservation of Goat Skins"Approach for cleaner leather manufacture.

[27]. Sumita Dixit, etal. (2014) "Toxic Hazards Of Leather Industry and Technologies to Combat Threat-a Review", JCP 87 (39-49).

[28]. Eaton AD, Clesceri LS, Greenber AE. (1995) Standard Methods of the Examination of Water and wastewater, 20th ed. Washington, DC: APHA.

[29]. Musa A. E and Gasmel seed G.A (2012) "Characterization of Lawsoniainermis (Henna) as Vegetable Tanning Material", Journal of forest products \& industries, 1(2) p.35
[30]. Michael Black, et al (2013) "Best Available Techniques (BAT) Reference Document for the Tanning of Hides and Skins" - J R C. reference report.

[31]. [GetanehAndualem and Dr. B. Madhan (2014) "Combination Tanning Based on Tara and sodium meta silicate a New Chrome Free Tanning System". Thesis of a case study.

[32]. SivabalanV.and A. jayanthi (2009) "A Study to Reduce Salt Usage in Preservation of Skins and Hides with Alternate use of Plant Extract", 4 (6).

[33]. Ramesh Duraisamy, SeguyeShamena and AbiyukereboBerekute (2016) "A Review of Biotanning Materials for Processing of Fish Skin into Leather", International Journal of Engineering Trends and Technology (IJETT) 39 (1) pp.10-20.

[34]. Rolland W (2014) "Vegetable Tanning in Bolgatanga: Challenges and the Way Forward. Arts and Design Studies" 16, pp.27-37.

[35]. Selma A. Hussein, (2017) "Utilization of Tannins Extract of Acacia Seyal Bark (Taleh) in Tannage of Leather", Journal of Chemical Engineering \& Process Technology.

[36]. Koloka, O. and Moreki, J. C. (2011) “Tanning Hides and Skins using Vegetable Tanning Agents inHukuntsi Sub-District, Botswana", Journal of Agricultural Technology,7, p.915.

[37]. Alex Kuria, et al. (2016) "Quality Evaluation of Leathers Produced By Selected Vegetable Tanning Materials from Laikipia County, Kenya", IOSR Journal of Agriculture and Veterinary Science (IOSR-JAVS), 9.

[38]. Haslarn, E., (1993) "Polyphenol Complexation", Leather, pp.59-71.

[39]. Assefa (et al 2010) "Ethnomedicinal Uses of Hageniaabyssinica (Bruce) J.F. Gmel. Among Rural Communities of Ethiopia", Journal of Ethnobiology and Ethnomedicine6 (20).

[40]. VincenzonLattanzio (2013) "Phenolic Compounds", Department of Sciences of Agriculture, Food and Environment, University of Foggia, Foggia, Italy, p. 1543.

[41]. BIS (2007) "Methods of Test for Vegetable Tanning Materials". Doc: CHD17 (1627) C, (59) pp.140.10.

[42]. Covington T. Tanning chemistry (2009) "The Science of Leather", TheRoyal Society of Chemistry, Thomas Garahan House, Science Park, Cambridge Cb4 OWF, UK. 